\author{
Joanna Kosmaczewska* \\ University of Economy in Bydgoszcz
}

\title{
THE NEGATIVE EFFECTS OF TOURISM DEVELOPMENT IN THE PERCEPTION OF RESIDENTS OF DIFFERENT TYPES OF RURAL COMMUNITIES
}

\begin{abstract}
The main objective of the article is to determine the perception of negative effects of tourism development observed among the residents of different types of rural communities. In the paper, it is assumed that negative effects of tourism development can be perceived by the residents of tourist resorts from the economic, social, cultural and environmental points of view. Having verified previously taken hypotheses, it has been found out that significant statistical differences observed in the perception of tourism development among the residents of different types of rural communities merely concern goods and services prices rise, which appears to be the only negative effect of tourism development perceived by the residents of the particular community. Furthermore, no statistically important relationship between the influence of tourism development on the respondents' income and their perception of its negative effects analysed here, has been found.
\end{abstract}

Keywords: residents' attitudes, host perceptions, rural tourism, local community

\section{Introduction}

In Poland, sustainability is considered to be one of the basic principles of the government's policy towards the development of agriculture and rural areas. In principle, it assumes multi-functionality, however a significant role has

* E-mail address: joanna.kosmaczewska@byd.pl. 
also been assigned to tourism since, as the economic, social, cultural and environmental phenomenon, it displays numerous factors stimulating regional and local development. Most frequently, it is perceived through the lens of economic profits gained by local accommodation providers, local communities as well as local authorities.

It has been observed that among the effects of tourism development presented in literature, there are some of economic character, but also those showing non-economic character which, in fact, should not be considered to be less important. It must be also emphasized here that the above mentioned effects can have either a positive or negative dimension for the development of a local area as well as for all the local stakeholders. The possibility of getting some measurable income by local service providers as well as by other countrymen, stimulation of economic initiatives, creation of new workplaces together with increasing women's professional activity, represent these positive effects of tourism development that are of economic character. However, tourism development can also lead to some negative phenomena, such as seasonality of services and temporary price rise of goods and services. Such issues as the ability of reaching a higher social position by countrymen, improving their lifestyle, maintaining local customs and traditions, getting opened to the world can definitely be described as positive effects of tourist development found in social and cultural areas. Unfortunately, there are some likely drawbacks of tourism development that must be mentioned such as commercialization of customs and traditions, polarisation of local communities or devastation of natural environment.

Apart from the tourist attractiveness of a particular area, its residents' willingness for providing tourist services, support received from local authorities and any other institutions popularizing tourism development in certain places, the attitude of local residents themselves shown towards the visitors to their community seems to be a vital factor influencing a tourism development process. Guests visiting a particular tourist site will feel much more comfortable and relaxed if they see the acceptance shown by the locals or, on the contrary, they are very likely to feel great discomfort if they notice the lack of such acceptance. It must be also emphasized that in the future, local residents themselves are very likely to become providers of the services indirectly connected with the presence of tourists. Hospitality of a tourist destination can be considered as two different grounds - a hospitable space or a hospitable community. J. Kaczmarek, A. Stasiak, B. Włodarczyk define the hospitable space as the way of developing 
the area in such a way that would enable a safe and comfortable stay of the visitors and they also associate the arrangement of a tourist destination space with the local residents' attitudes. They do it by means of the hospitality formula ${ }^{1}$ they created. Therefore, it can be assumed that if the higher proportion of local residents show care and assistance towards the visitors, the more hospitable the certain local community is. As the above considerations show, the hospitality of a tourist destination is the resultant of the area development level and the local residents' attitudes.

Thus, the main aim of the article is to determine the perception of negative effects of tourism development shown by the residents of various types of rural communities. In the paper, it was assumed that negative effects of tourism development can be perceived by the residents of tourist resorts from economic, social, cultural and environmental points of view. Therefore, in this paper, three research hypotheses were put forward to be verified later with the use of Spearman's rank correlation coefficient, which describes the dependence between two variables using a monotonic function, and ANOVA Kruskala-Wallis test.

The article is organised as follows: a review of the literature; an explanation of the methodology corresponding to the presented empirical research; results and discussion with main conclusions.

\section{Residents' perception of tourism - literature review}

Perception of tourism shown by the residents of tourist resorts has been recognized and described relatively well in literature. The research concerning host-guest relations goes back as far as to the late $60 \mathrm{~s}(1960 \mathrm{~s}){ }^{2}$ As the research results show, local residents' attitudes towards tourists can significantly determine the level of satisfaction or dissatisfaction of the holiday trip made by the latter. ${ }^{3}$ Each local community seems to consist of residents who show a very positive at-

1 J. Kaczmarek, A. Stasiak, B. Włodarczyk, Hospitable space-a few remarks on the competitiveness of regions, in: Tourism as the stimulating factor of the competitiveness of regions in times of globalization, ed. G. Gołembski, Akademia Ekonomiczna, Poznań, 2008, pp. 136-150.

2 R. Sharpley, Host perceptions of tourism: A review of the research, "Tourism Management" 2014, No. 42, pp. 37-49.

3 Ibidem. 
titude towards tourism development as well as of the ones who totally disapprove of this process. However, between these two extreme ones, there are numerous groups that consist of the residents who are unable to express their precise attitude towards tourism development. ${ }^{4}$ Social Exchange Theory ${ }^{5}$ is the means most frequently used to explain local residents' attitude towards tourists. According to the above mentioned theory, an individual is aiming at profit maximisation, the chance for which appears in particular social situations, and is willingly taking part in the exchange process if the expected profits exceed costs. Therefore, in the analysed case, it means that the residents are very willing to express their positive attitude towards the visitors if they perceive such behaviour as something that is likely to bring them profits higher than costs. ${ }^{6}$ However, it must be emphasized that residents' attitude towards tourists and tourism development in the area of their residence is not permanent and shows the tendency to undergo changes as time goes by. Allen et al. (1988) found that residents' perception of tourism impacts became less positive as the level of tourism in a community increased.?

The results of empirical studies conducted by numerous researchers allowed to determine a set of variables which appear to influence the perception of the effects of tourism development. Most frequently, they are presented as two separate groups, i.e. extrinsic variables and intrinsic variables. The group of extrinsic variables, which significantly affect the residents' attitudes towards tourism development and the tourists themselves, includes, among others,

4 K. Andritios, V. Vaughan, Urban residents' attitudes toward tourism development: the case of Crete, "Journal of Travel Research" 2003, No. 42 (2), pp. 172-185; E. Perez, J. Nadal, Host community perceptions: a clyster analysis, “Annals of Tourism Research” 2005, No. 32 (4), pp. 925-941.

5 C. Jurowski, D. Gursoy, Distance effects on residents' attitudes toward tourism, "Annals of Tourism Research" 2004, No. 31 (2), pp. 296-312; K. Andereck, K. Valentine, R. Knopf, C. Vogt, Residents' perceptions of community tourism impacts, "Annals of Tourism Research" 2005, No. 32 (4), pp. 1056-1076; B. Bestard, R. Nadal, Attitudes toward tourism and tourism congestion, "Region et Developpment" 2007, No. 25, pp. 193-207; Y. Wang, R. Pfister, Residents" attitude toward tourism and perceived personal benefits in a rural community, "Journal of Travel Research" 2008, No. 47 (1), pp. 84-93; R. Nunkoo, D. Gursoy, Residents' support for tourism: an identity perspective, "Annals of Tourism Research" 2012, No. 39 (1), pp. 243-268.

6 P. Látková, A. Vogt, Residents' Attitudes toward Existing and Future Tourism Development in Rural Communities, "Journal of Travel Research" 2012, No. 51 (1), pp. 50-67.

7 L. Allen, P. Long, R. Perdue, S. Kieselbach, The impact of tourism development on residents' perceptions of community life, "Journal of Travel Research" 1998, No. 27 (1), pp. 16-21. 
the level (stage) of tourism development, ${ }^{8}$ the type of tourism being developed and the type and number of tourists deciding to visit a particular destination. ${ }^{9}$ Moreover, perceptions of tourism are found to vary according to seasonality and national stage of development. The less economically developed the destination, the more positively are the opportunities presented by tourism perceived. ${ }^{10}$ Empirical studies show that statistically important intrinsic variables include demographic features, such as: age, sex and education level. ${ }^{11}$ Moreover, some correlation has been found to exist between residents' social status and the extent to which they identify themselves with the destination. ${ }^{12}$ As Cui and Ryan $(2011)^{13}$ demonstrated, the relationship between place attachment and tourism has been seen differently by urban and rural residents, with rural areas expressing more concern. Also contact or interaction with tourists has been found to be correlated positively with support for tourism, though it may also depend on the type of tourists and the frequency of the contacts. ${ }^{14}$ As the results of studies conducted

8 A. Leep, Attitudes towards initial tourism development in a community with no prior experience: the case of Bigodi, Uganda, "Journal of Sustainable Tourism" 2008, No. 16 (1), pp. 5-22; A. Vargas-Sanchez, M. Plaza-Mejia, N. Porras-Bueno, Understanding residents' attitudes toward the development of industrial tourism in a former mining community, "Journal of Travel Research" 2009, No. 47 (3), pp. 373-387.

9 J. Johnson, D. Snepenger, S. Akis, Residents' perceptions of tourism development, "Annals of Tourism Research" 1994, No. 21 (3), pp. 629-642; B. Bestard, R. Nadal, Attitudes toward tourism and tourism congestion, "Region et Development" 2007, No. 25, pp. 193-207; A. VargasSanchez, N. Porras-Bueno, M. Plaza-Mejia, Explaining residents attitudes to tourism: is a universal model possible?, “Annals of Tourism Research” 2011, No. 38 (2), pp. 460-480.

10 A. Leep, Residents' attitudes toward tourism in Bigodi village, Uganda, "Tourism Management" 2007, No. 28 (3), pp. 876-885.

11 P. Mason, J. Cheyne, Residents' attitudes to proposed tourism development, “Annals of Tourism Research" 2000, No. 27 (2), pp. 391-411; C. Tosun, Host perceptions of impacts: a comparative tourism study, "Annals of Tourism Research" 2002, No. 29 (1), pp. 231-253; C. Huh, C. Vogt, Changes in residents' attitudes toward tourism over time: a cohort analytical approach, "Journal of Travel Research" 2008, No. 46 (4), pp. 446-455.

12 R. Nunkoo, D. Gursoy, Residents' support for tourism: an identity perspective, "Annals of Tourism Research" 2012, No. 39 (1), pp. 243-268; A. Palmer, N. Koenig-Lewis, L. Jones, The effects of residents' social identity and involvement on their advocacy of incoming tourism, “Tourism Management" 2013, No. 38 (1), pp. 142-151.

13 X. Cui, C. Ryan, Perceptions of place, modernity and the impacts of tourism-Differences among rural and urban residents of Ankang, China: A likelihood ratio analysis, "Tourism Management" 2011, No. 32 (3), pp. 604-615.

14 K. Andereck, K. Valentine, R. Knopf, C. Vogt, Residents' perceptions of community tourism impacts, "Annals of Tourism Research" 2005, No. 32 (4), pp. 1056-1076. 
by other researchers show, the greater proximity to the tourism zone, the more negative are perceptions of tourism. ${ }^{15}$

As it can be seen from this literature review, perception of effects of tourism development as well as the attitude towards tourists are determined by numerous variables. Broader review of appropriate literature concerning these aspects was done by R. Sharpley (2014). ${ }^{16}$

\section{Rural communities typology - short description of methodology}

Three basic factors influencing tourism development have been considered in order to present the typology of rural communes:

- commune's economic and social situation,

- commune's resourcefulness,

- commune's tourist attractiveness.

Tourism development in a particular type of a commune, especially its economic and social effects, strictly depend on mutual relationships taking place between the three above mentioned factors, however a crucial issue is not only if a particular tourism development factor acts as its stimulant or not, but also what kind of relationship it shows towards the remaining factors of tourism function development.

Each factor has been expressed by means of an aggregate indicator. In order to assess economic and social resources, the development level indicator has been created (WPR), for commune's resourcefulness assessment, the resourcefulness indicator (WZF) has been used and finally, for tourist attractiveness assessment, the tourism development indicator (WRT) has been applied. The components of development level indicator are showed in Table 1 Tourism development aggregate indicator's structure is showed at Table 2.

\footnotetext{
15 C. Raymond, G. Brown, A spatial method for assessing resident and visitor attitudes towards tourism growth and development, "Journal of Sustainable Tourism" 2007, No. 15 (5), pp. 520-540; B. Sharma, P. Dyer, An investigation of differences in residents' perceptions on the Sunshine Coast: tourism impacts and demographic variables, "Tourism Geographies: An International Journal of Tourism Space, Place and Environment” 2009, No. 11 (2), pp. 187-213.

16 R. Sharpley, Host perceptions of tourism: A review of the research, "Tourism Management" 2014, No. (42), pp. 37-49.
} 
Development level indicator's structure (WPR)

\begin{tabular}{|c|c|}
\hline $\begin{array}{l}\text { Development Level } \\
\text { Indicator (WPR) }\end{array}$ & Sub-indicators \\
\hline \multirow{2}{*}{ Social component } & migration attractiveness indicator \\
\hline & $\%$ of the community using water supply and sewerage networks \\
\hline \multirow{4}{*}{$\begin{array}{l}\text { Economic } \\
\text { component }\end{array}$} & commune's budget expenditure per capita \\
\hline & commune's own income per capita \\
\hline & enterprise indicator \\
\hline & $\begin{array}{l}\% \text { of the registered unemployed per the total number of inhabitants } \\
\text { in productive age }\end{array}$ \\
\hline
\end{tabular}

Source: based on literature review.

Table 2

Tourism development aggregate indicator's structure (WRT)

\begin{tabular}{|c|c|}
\hline \multirow{11}{*}{ WRT } & Sub-indicators \\
\hline & intensity of tourist activity indicator (Schneider's) \\
\hline & a place's tourist function indicator (Baretje's and Defert's) \\
\hline & tourist function indicator (Defert's) \\
\hline & accommodation development indicator \\
\hline & accommodation accessibility indicator \\
\hline & forests \\
\hline & parks and greenery \\
\hline & cultural attractiveness indicator \\
\hline & $\begin{array}{c}\text { businesses registered in the national economy register REGON in section } \mathrm{H} \text { per } 1000 \\
\text { people in productive age }\end{array}$ \\
\hline & expenditure on culture and national heritage protection per capita \\
\hline
\end{tabular}

Source: based on literature review.

The resourcefulness indicator (WZF) has been calculated as follows:

$$
W Z F=\frac{p}{L}-\frac{s+d}{L}
$$

where:

$p$-stands for share in taxes being the part of state budget income,

$s-$ stands for general subsidies,

$d$-stands for budget grants in total,

$L-$ stands for a number of inhabitants

If the above mentioned indicators happen to express positive values, these indicators are described as tourism development stimulants, however if their 
values drop and become negative, they are considered to be the ones that hamper tourism development in a commune.

With regard to the next stage of presenting rural areas typology, it is not important to decide if the particular indicators depicting tourism development factors show stimulating or hampering character, because at this point, these indicators show some exact values. Such a situation allow to create four empirical typological groups. The main criterion used for including a commune into a particular group is the relationship between the values showed by particular aggregate indicators. On this basis, the following 4 groups have been distinguished: 1. Well-developed communes with a dominating non-tourist function WZF $>$ WPR $>$ WRT. ${ }^{17}$

2. Averagely developed communes where a tourist function is significant WZF $>$ WPR $\geq$ WRT.

3. Poorly developed communes but with tourist potentials $\mathrm{WZF}<\mathrm{WPR} \leq$ WRT.

4. Very poorly developed communes of non-tourist character WZF $<$ WPR $<$ WRT.

The suggested division into four empirical typological groups corresponds with the division into integrated rural areas, in between rural areas and peripheral rural areas. Thus, it can be assumed that the communes that are:

1. Well-developed with a dominating non-tourist function WZF $>$ WPR $>$ WRT represent integrated rural areas and later in the article will be referred to as "satellite communes" (Osielsko commune).

2. Averagely developed where a tourist function is significant WZF $>$ WPR $\geq$ WRT represent in between rural areas with a developed tourist function and later in the article will be referred to as "star communes" (Miasteczko Krajeńskie commune, Przechlewo commune, Dragacz commune).

3. Poorly developed but with tourist potentials $\mathrm{WZF}<\mathrm{WPR} \leq \mathrm{WRT}$ represent in between rural areas with a non-developed tourist functions, but showing tourism development potentials and later in the article will be referred to as "aspiring star communes" (Liniewo commune, Lipka commune).

\footnotetext{
17 The used pattern means that the value of commune's resourcefulness indicator (WZF) for this type of communes is higher than the values of the development level indicator (WPR) and the tourism development indicator (WRT).
} 
4. Very poorly developed of non-tourist character WZF $<$ WPR $<$ WRT represent peripheral rural areas and will be referred to as "stone communes" (Czernikowo commune, Chrostkowo commune). ${ }^{18}$

\section{Methodology of the research}

The main objective of the article is to determine the perception of negative effects of tourism development observed among the residents of different types of rural communities. The assumption is that the negative effects of tourism development can be perceived by the residents of tourist resorts from the economic, social, cultural and environmental points of view. Therefore, in the survey, the residents of particular types of communities were asked to express their opinions on perception of negative effects of tourism development with particular respect to the following phenomena: goods and services price rise (economic dimension), the fact that only accommodation providers become rich (social and cultural dimension, polarisation), and degradation of natural environment.

The paper takes into consideration the following hypotheses:

$\mathrm{H}_{1}$ lack of statistically significant influence of the features determining the community type on the residents' perception of goods and services price rise as the negative effect of tourism development.

$\mathrm{H}_{2}$ lack of statistically significant influence of the features determining the community type on the residents' perception of the fact that only accommodation providers become rich as the negative effect of tourism development.

$\mathrm{H}_{3}$ lack of statistically significant influence of the features determining the community type on the residents' perception of natural environment degradation as the negative effect of tourism development.

In order to verify the presented above hypotheses, empirical research was carried out among the residents of various types of communities, and then, the obtained results were analysed. The research was conducted among the residents of the communities representing particular community types, on random sample of 1000 people of working age. In relation to the total number of people inhabiting the mentioned communities, which is 32,048 in toto, the research concerned

18 J. Kosmaczewska, Tourism as a factor in the development of rural areas, Bogucki Publishing, Poznań 2013. 
only $3.12 \%$ of all the residents of working age. In order to determine the sample size, the formula for minimum sample size was applied where the fraction was assumed to be on the level of $50 \%$, the confidence coefficient on the level of 0.95 and the maximum standard error on the level of $3.15 \%$. Then, the sample was divided into categories considering the total number of working age people living in the community. The effects are presented in the table below.

Table 3

Methodology of selecting the sample for the research

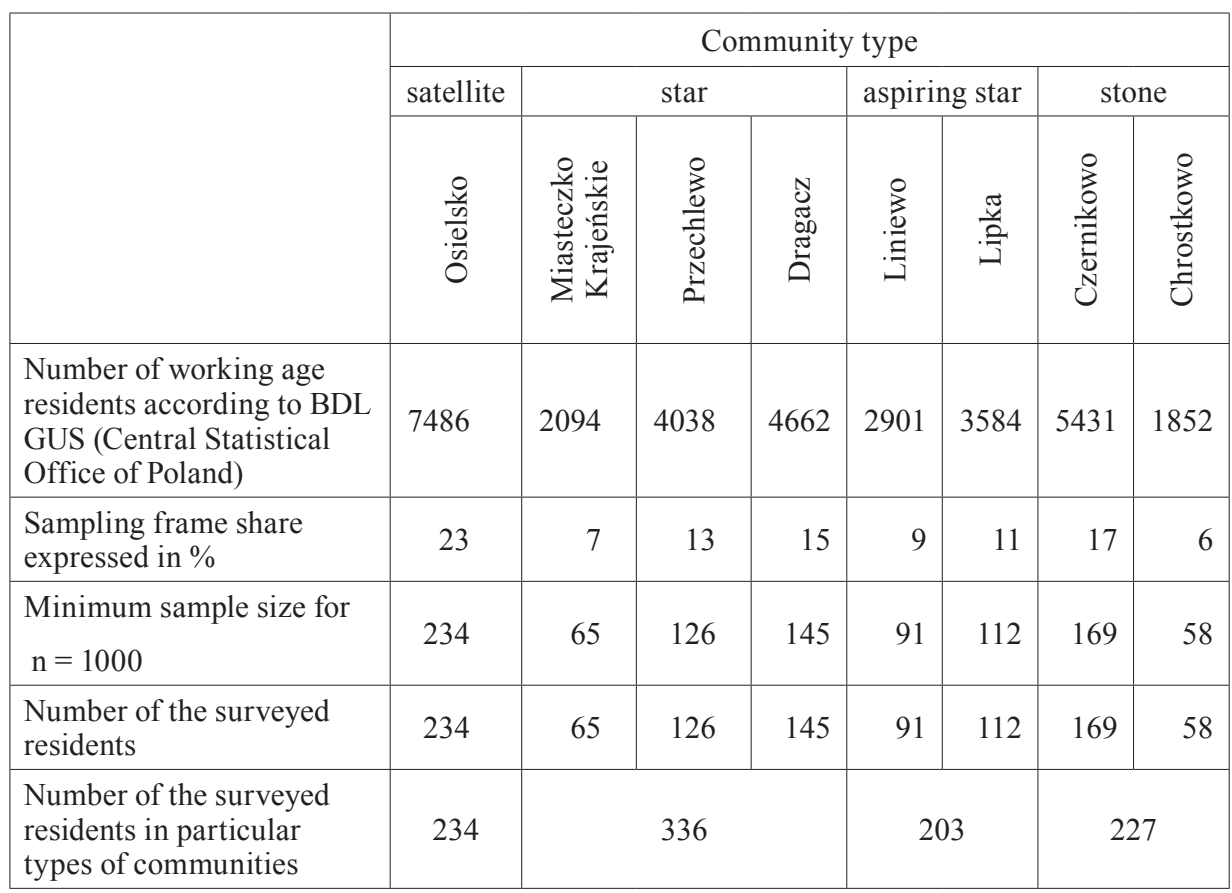

Source: GUS (Central Statistical Office of Poland).

Next, the surveyed population was divided into categories according to such features as age and sex. In order to verify the appropriateness of the survey and find out how well the qualified interviewers were prepared to conduct it, the right survey was preceded by the mock survey. ${ }^{19}$ Due to the lack of regular distribution of the obtained data, necessary for the statistical analysis, ANOVA Kruskala-Wallis test was used, and in the case of obtaining statistical significance,

19 The research was conducted in 2011 by Bio-Stat, an experienced research company, with the use of CATI technique (Computer Assisted Telephone Interviewing). 
multiple comparison tests were applied. Additionally, in descriptive analyses, number and percentage indicators were used.

\section{Results}

The value of the test statistics of ranks obtained by means of ANOVA Kruskala-Wallis test, $\mathrm{H}(3, \mathrm{~N}=1000)=15.856 ; \mathrm{p}=.0012$ allows to reject $\mathrm{H}_{0}$ and take the alternative hypothesis assuming that there exists a statistically significant impact of the features determining a community type on goods and services price rise perception as the negative effect of tourism development. As the results presented in the Figure 1 show, the perception of goods and services price rise as the negative effect of tourism development was most frequently pointed out by the residents of stone type communities, that is, ones where the level of tourism development seems to be the lowest of all the analysed community types.

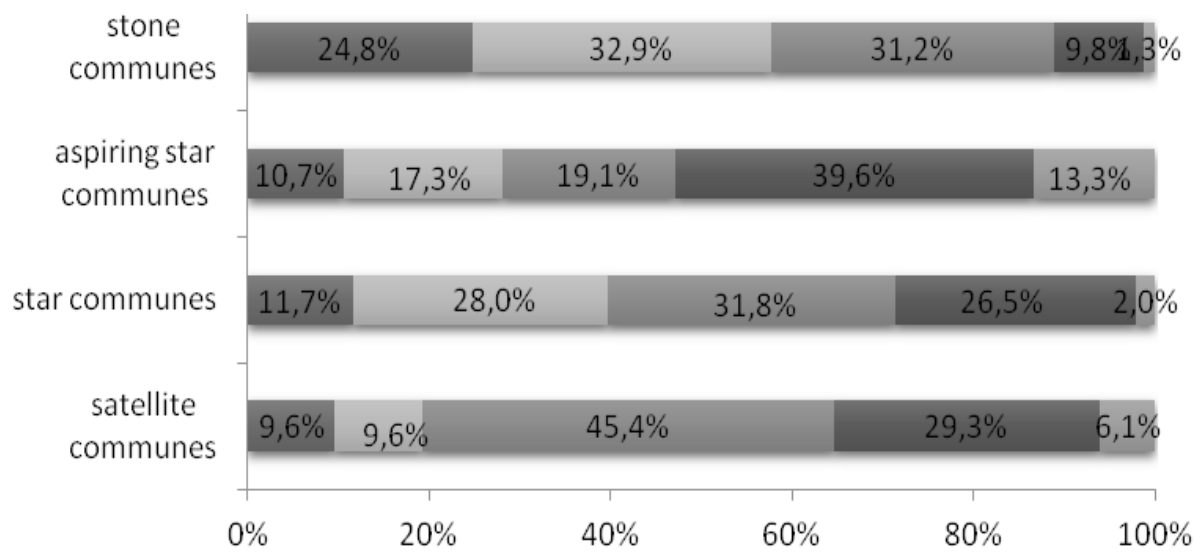

- Strongly agree $\quad$ Agree $\square$ Undecided Disagree $\quad$ Strongly disagree

Fig. 1. Percentage distribution of the respondents' answers - goods and services price rise

Source: own research. 
The results of multiple comparison tests demonstrate that the statistically significant differences between the answers given by the residents of two extreme community types: satellite and stone, are responsible for $\mathrm{H}_{0}$ rejection. The respondents from the satellite communities much more frequently (29.3\%) than those inhabiting the stone type communities $(9.8 \%)$ disagree with the opinion that tourism development is likely to cause goods and services price rise. However, the lowest result concerning the above mentioned negative effect of tourism development has been observed in the responses given by the inhabitants of the aspiring stars community types, that is, the ones which would willingly become tourist destinations.

Table 4

Value of $p$ obtained in multiple comparison test of ranks with the use of ANOVA Kruskala-Wallis test concerning goods and services price rise as the result of tourism development for the variable grouping a community type.

\begin{tabular}{|l|c|c|c|c|}
\hline & $\begin{array}{c}\text { Satellite } \\
\text { communes }\end{array}$ & $\begin{array}{c}\text { Star } \\
\text { communes }\end{array}$ & $\begin{array}{c}\text { Aspiring star } \\
\text { communes }\end{array}$ & $\begin{array}{c}\text { Stone } \\
\text { communes }\end{array}$ \\
\hline Satellite communes & 1.000000 & 1.000000 & 0.108885 & $0.001692^{*}$ \\
\hline Star communes & 0.108885 & 1.000000 & 1.000000 & 0.053072 \\
\hline $\begin{array}{l}\text { Aspiring } \\
\text { star communes }\end{array}$ & $0.001692^{*}$ & 0.053072 & 1.000000 & 1.000000 \\
\hline Stone communes & & & \\
\hline
\end{tabular}

* statistically significant differences observed between various groups $(\mathrm{p}<0.05)$ Source: own research.

Additionally, the results of Spearman's test of ranks show that the perception of goods and services price rise as the negative effect of tourism development appear not to depend on education level $(p=-0.002)$ or $\operatorname{sex}(p=0.019)$ of the respondents, but only on their age $(p=0.097)$. The older the respondents, the more frequently they agree with the opinion that tourism development causes goods and services price rise.

Although a brief analysis of the survey's percentage results suggests that the residents of stone type communities most frequently agree with the opinion that tourism development brings significant profits only to accommodation providers and makes them richer (46.1\% strongly agree and agree), a statistical analysis $\mathrm{H}(3, \mathrm{~N}=1000)=4.017672 ; \mathrm{p}=0.2596$ does not give any basis to reject $\mathrm{H}_{0}$. Therefore, it must be assumed that perceiving the phenomenon 
of only accommodation providers getting rich as the negative impact of tourism development, does not depend on the features determining the community type the respondents reside.

Therefore, having analysed the responses given by all the respondents $(\mathrm{N}=1000)$ it can be observed that $25.1 \%$ agree or strongly agree $12.1 \%$, that tourism development in their community brings visible profits only to accommodation providers. The analysis of the obtained results shows that perceiving the fact of only accommodation providers getting rich as the negative effect of tourism development is affected neither by the respondents' age $(p=0.041)$, education level $(\mathrm{p}=-0.017)$ nor by their $\operatorname{sex}(\mathrm{p}=0.005)$.

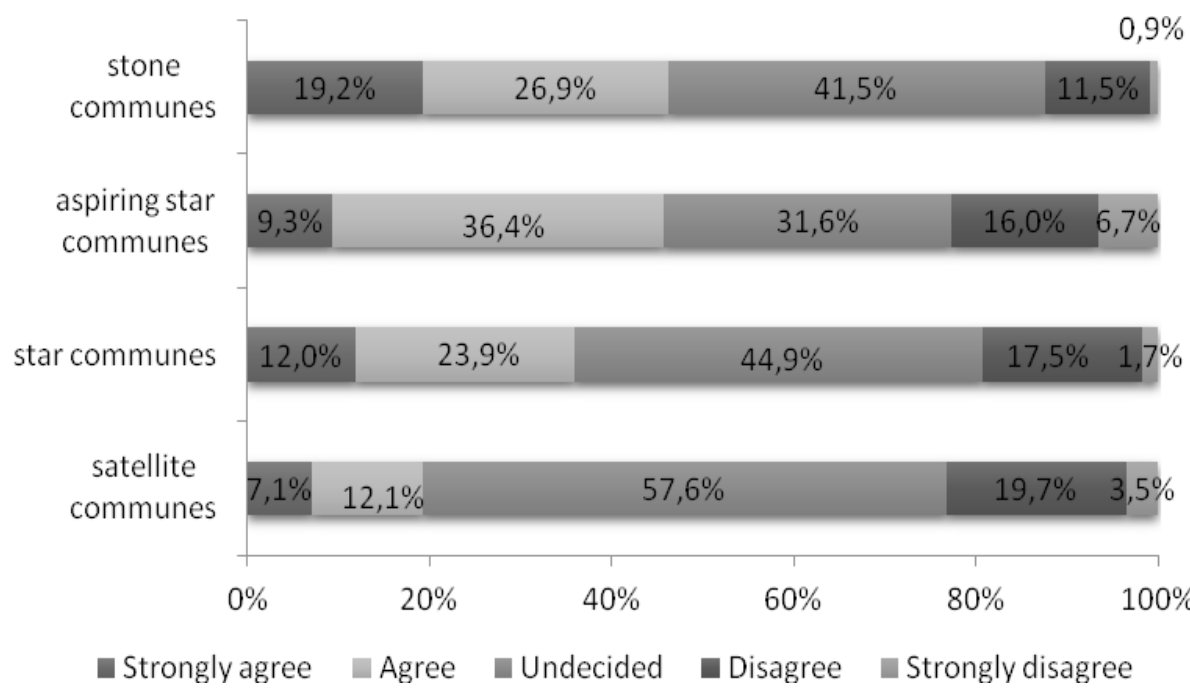

Fig. 2. Percentage distribution of the respondents' answers - only accommodation providers getting rich

Source: own research.

The above discussed analyses also demonstrate the lack of statistically significant influence $\mathrm{H}(3, \mathrm{~N}=1000)=7.408878 ; \mathrm{p}=0.0599$ of the features determining the community type on their residents' perception of natural environment degradation as the negative effect of tourism development. However, the natural environment degradation perceived as the negative effect of tourism development appears to be treated by the majority of the respondents in a relatively gentle way, since $44.1 \%$ of them disagreed with the suggestion that tourism development 
might cause natural environment degradation in their community. The analysis of the results does not find the perception of natural environment degradation as the negative effect of tourism development to be affected by the respondents' age $(p=0.052)$, education level $(p=-0.029)$ or $\operatorname{sex}(p=-0.004)$.

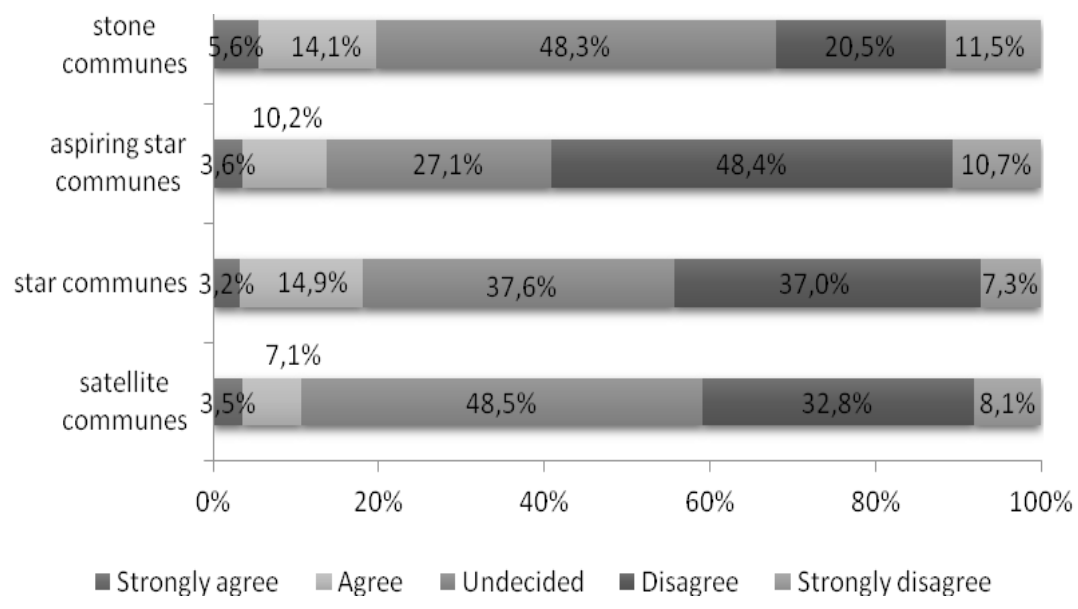

Fig. 3. Percentage distribution of the respondents' answers - natural environment degradation

Source: own research.

In the article, the relationship between the perception of negative impact of tourism development and the respondents' readiness for opening up tourist services-related enterprises has also been analysed. In addition, a statistically significant dependence has been found out. The more interested in opening up enterprises servicing tourists the respondents seemed to be, the more frequently they perceived the negative effects of tourism development such as: goods and services price rise $(\mathrm{p}=0.233)$, only accommodation providers getting rich $(p=0.202)$ and natural environment degradation $(p=0.084) .{ }^{20}$ On the other hand, no relationship between tourism influence on the level of the respondents' income and their perception of the above analysed negative effects of tourism development has been observed. ${ }^{21}$

20 Correlations are significant with $\mathrm{p}<0.05$.

${ }_{21}$ Goods and services price rise $(\mathrm{p}=0.043)$, only accommodation providers getting rich $(p=0.050)$ and natural environment degradation $(p=0.037)$, at significance level with $p<0.05$. 


\section{Conclusion}

Some researchers point out that people who profit from tourism development are much more likely, compared to others, to accept the influence tourism has on their environment. ${ }^{22}$ The empirical research conducted by the author of this article in 2005 in four communities of the Great Poland Province (sample size -765 people), showed that the residents' attitude towards tourists is highly affected by their age and education level, but most of all, it appears to be strongly connected with perceiving agritourism as a potential source of the respondents' income. ${ }^{23}$ However, the results presented in the article do not seem to confirm the above assumption, since no statistically significant relationship between tourism influence on the level of the respondents' income and their perception of the analysed negative effects of tourism development, has been observed.

The obtained research results are similar to those of Madrigal (1993) where personal economic reliance (defined as dependence of respondent's income on the tourism industry) has been found to be significantly related to positive perceptions of tourism though there is no significant relationship between personal economic reliance and negative perceptions of tourism. ${ }^{24}$ However, the relationship between the perception of negative impact of tourism development and the respondents' readiness for opening up tourist services related enterprises has been demonstrated. Besides, the perception of negative effects of tourism development has not appeared to be affected by either sex or education level of rural communities residents. Nevertheless, I. Sikorska-Wolak and J. Zawadka, in their work, observed that the higher the residents' education level, the more positive their attitude towards tourism development ${ }^{25}$. The respondents'

\footnotetext{
K. Andereck, K. Valentine, C. Vogt, R. Knopf, A cross-cultural analysis of tourism and quality of life perceptions, "Journal of Sustainable Tourism" 2007, No. 15 (5), pp. 483-502; D. Gursoy, C. Chi, P. Dyer, An examination of loclas' attitudes, "Annals of Tourism Research" 2009, No. 36 (4), pp. 715-734; M. Mika, Attitudes of local communities towards tourists and tourism development - the example of municipalities in the Silesian Beskidy Mountains, "Prace Geograficzne" 2013, No. 134, pp. 83-100.

23 J. Kosmaczewska, Influence of agritourism on a community economic and social development, Bogucki Wydawnictwo Naukowe, Poznań 2007.

24 R. Madrigal, A Tale of Tourism in Two Cities, "Annals of Tourism Research" 1993, No. 20 (2), pp. 336-53.

25 I. Sikorska-Wolak, J. Zawadka, Attitudes of the local community towards the development of rural tourism, "Folia Pomer. Univ. Technol. Stetin Oeconomica" 2011, No. 288 (64), pp. 93-102.
} 
age turns out to be important only in the case of perception of goods and services price rise as the negative effect of tourism development. The similar situation has been observed in the research conducted by M. Mika according to which the respondents' age appeared to affect the assessment of subjectively felt nuisance of tourism. ${ }^{26}$

However, the main aim of the article is to determine the perception of negative effects of tourism development by residents of various types of rural communities. The obtained results demonstrate that statistically significant differences observed in perception of negative effects of tourism development by residents of various community types, basically concern only the perception of goods and services price rise. Such attitudes are most frequently presented by the residents of the stone type communities where tourism development level appears to be the lowest in all analysed community types. On the other hand, residents of the satellite type communities hardly considered goods and services price rise as the negative effect of tourism development.

Thus, it can be presumed that these statistically significant differences found in the responses given by residents of two extreme community types reflect a general economic situation of these communities. Since the stone type communities are described as very poorly developed of a non-tourist character, and the satellite type communities as well-developed with a dominating nontourist function, it can be assumed that the respondents are simply unable to distinguish the development factors that affect goods and services price rise other than tourism, especially when the stone type communities residents are said to be more sensitive to any price growth than the residents of other community types. As the results of the research done by Allen et al. (1993) have shown, the relationship between tourism development level and economic development level of a particular community, turns out to have undoubtable influence on residents' attitudes towards tourists and tourism itself. Communities with low tourism development and low total economic activity, as well as communities with high tourism development and high total economic activity, view tourism development

\footnotetext{
${ }^{26}$ M. Mika, Attitudes of local communities towards tourists and tourism developmentthe example of municipalities in the Silesian Beskidy Mountains, "Prace Geograficzne" 2013, No. 134 , pp. 83-100.
} 
more favourably than communities with low tourism and high economic activity and communities with high tourism development and low economic activity. ${ }^{27}$

Different opinions and attitudes of the residents of selected local municipalities in the Silesian Beskidy Mountains - Brenna, Istebna, Ustroń, Wisła - towards tourists and the nuisance of tourism are presented in the research conducted by M. Mika. Also, a place identity plays an active role in influencing residents' attitudes towards tourism with respect to negative and positive tourism impacts. ${ }^{28}$

Summing up, it must be said that residents' attitude towards tourism development in their communities appears to be determined by a number of factors and conditions of economic, social and cultural nature. Therefore, the further analysis of the residents' attitudes towards tourism development with regard to factors describing a community type seems to be necessary and fully justified.

\section{References}

Allen L., Hafer H., Long P., Perdue R., Rural Residents' Attitudes toward Recreation and Tourism Development, "Journal of Travel Research" 1993, No. 31 (4).

Allen L., Long P., Perdue R., Kieselbach S., The impact of tourism development on residents' perceptions of community life, "Journal of Travel Research" 1988, No. 27 (1).

Andereck K., Valentine K., Vogt C., Knopf R., A cross-cultural analysis of tourism and quality of life perceptions, "Journal of Sustainable Tourism" 2007, No. 15 (5).

Andereck K., Valentine K., Knopf R., Vogt C., Residents' perceptions of community tourism impacts, "Annals of Tourism Research" 2005, No. 32 (4).

Andritios K., Vaughan V., Urban residents' attitudes toward tourism development: the case of Crete, "Journal of Travel Research" 2003, No. 42 (2).

Bestard B., Nadal R., Attitudes toward tourism and tourism congestion, "Region et Developpment" 2007, No. 25.

Cui X., Ryan C. Perceptions of place, modernity and the impacts of tourism-Differences among rural and urban residents of Ankang, China: A likelihood ratio analysis, “Tourism Management" 2011, No. 32 (3).

Gursoy D., Chi C., Dyer P., An examination of loclas' attitudes, “Annals of Tourism Research" 2009, No. 36 (4).

Huh C., Vogt C., Changes in residents' attitudes toward tourism over time: a cohort analytical approach, "Journal of Travel Research" 2008, No. 46 (4).

27 L. Allen, H. Hafer, P. Long, R. Perdue, Rural Residents' Attitudes toward Recreation and Tourism Development, "Journal of Travel Research" 1993, No. 31 (4), pp. 27-33.

$28 \mathrm{~S}$. Wang, $\mathrm{H}$. Xu, Influence of place-based senses of distinctiveness, continuity, self-esteem and self-efficacy on residents' attitudes toward tourism, "Tourism Management" 2015, No. 47, pp. 241-250. 
Johnson J., Snepenger D., Akis S., Residents' perceptions of tourism development, "Annals of Tourism Research" 1994, No. 21 (3).

Jurowski C., Gursoy D., Distance effects on residents' attitudes toward tourism, “Annals of Tourism Research" 2004, No. 31 (2).

Kaczmarek J., Stasiak A., Włodarczyk B., Hospitable space - a few remarks on the competitiveness of regions, in: Tourism as the stimulating factor of the competitiveness of regions in times of globalization, ed. G. Gołembski, Akademia Ekonomiczna, Poznań 2008.

Kosmaczewska J., Influence of agritourism on a community economic and social development, Bogucki Wydawnictwo Naukowe, Poznań 2007 (in Polish).

Kosmaczewska J., Tourism as a factor in the development of rural areas, Bogucki Publishing, Poznan, 2013 (in Polish).

Látková P., Vogt A., Residents' Attitudes toward Existing and Future Tourism Development in Rural Communities, "Journal of Travel Research" 2012, No. 51 (1).

Leep A., Residents' attitudes toward tourism in Bigodi village, Uganda, “Tourism Management" 2007, No. 28 (3).

Leep A., Attitudes towards initial tourism development in a community with no prior experience: the case of Bigodi, Uganda, "Journal of Sustainable Tourism" 2008, No. 16 (1).

Madrigal R., A Tale of Tourism in Two Cities, "Annals of Tourism Research" 1993, No. 20 (2).

Mason P., Cheyne J., Residents' attitudes to proposed tourism development, "Annals of Tourism Research" 2000, No. 27 (2).

Mika M., Attitudes of local communities towards tourists and tourism development - the example of municipalities in the Silesian Beskidy Mountains, "Prace Geograficzne" 2013, No. 134.

Nunkoo R., Gursoy D., Residents' support for tourism: an identity perspective, “Annals of Tourism Research" 2012, No. 39 (1).

Palmer A., Koenig-Lewis N., Jones L., The effects of residents' social identity and involvement on their advocacy of incoming tourism, "Tourism Management" 2013, No. 38 (1).

Perez E., Nadal J., Host community perceptions: a cluster analysis, "Annals of Tourism Research" 2005, No. 32 (4).

Raymond C., Brown G., A spatial method for assessing resident and visitor attitudes towards tourism growth and development, "Journal of Sustainable Tourism" 2007, No. 15 (5).

Sharma B., Dyer P., An investigation of differences in residents' perceptions on the Sunshine Coast: tourism impacts and demographic variables, "Tourism Geographies: An International Journal of Tourism Space, Place and Environment" 2009, No. 11 (2).

Sharpley R., Host perceptions of tourism: A review of the research, "Tourism Management" 2014, No. 42. 
Sikorska-Wolak I., Zawadka J., Attitudes of the local community towards the development of rural tourism, "Folia Pomer. Univ. Technol. Stetin.", "Oeconomica" 2011, No. 288 (64).

Tosun C., Host perceptions of impacts: a comparative tourism study, "Annals of Tourism Research" 2002, No. 29 (1).

Vargas-Sanchez A., Porras-Bueno N., Plaza-Mejia M., Explaining residents attitudes to tourism: is a universal model possible?, "Annals of Tourism Research" 2011, No. 38 (2).

Vargas-Sanchez A., Plaza-Mejia M., Porras-Bueno N., Understanding residents' attitudes toward the development of industrial tourism in a former mining community, "Journal of Travel Research" 2009, No. 47 (3).

Wang Y., Pfister R., Residents' attitude toward tourism and perceived personal benefits in a rural community, Journal of Travel Research 2008, No. 47 (1).

\section{NEGATYWNE EFEKTY ROZWOJU TURYSTYKI W PERCEPCJI MIESZKAŃCÓW RÓŻNYCH TYPÓW GMIN WIEJSKICH}

\section{Streszczenie}

Celem artykułu jest ocena postrzegania negatywnych efektów rozwoju turystyki przez mieszkańców różnych typów gmin wiejskich. W pracy przyjęto, że takie efekty mogą być zauważalne dla mieszkańców miejsc recepcji turystycznej w wymiarze ekonomicznym, społeczno-kulturowym i środowiskowym. W wyniku weryfikacji przyjętych hipotez stwierdzono, że istotne statystycznie różnice w percepcji mieszkańców różnych typów gmin dotyczą jedynie postrzegania wzrostu cen na artykuły i usługi jako negatywnego efektu rozwoju turystyki na terenie gminy. Ponadto nie stwierdzono statystycznie istotnego związku między wpływem turystyki na dochody respondentów a postrzeganiem przez nich analizowanych negatywnych efektów rozwoju turystyki.

Słowa kluczowe: postawy mieszkańców, percepcja mieszkańców, turystyka wiejska, społeczność lokalna 